\title{
Historical perspectives of The American Association for Thoracic Surgery: Thomas B. Ferguson (1923-2013)
}

\author{
Marc R. Moon, MD
}

Thomas Bruce Ferguson, 62nd president of The American Association for Thoracic Surgery (AATS), was born in Oklahoma City on May 6, 1923. His roots in Oklahoma ran deep, as his grandparents, Thompson and Elva Ferguson, were pioneer Oklahomans. They crossed into the Oklahoma Territory from Kansas during the "second run" for land claims in the early 1890s, when Dr Ferguson's father was 8 years old. "They literally shot a shotgun off at noon," Dr Ferguson recently recounted, "and went helterskelter as fast as they could until they found a plot of land that they liked and could stake a claim." * His grandparents settled in the Cherokee Outlet and started a newspaper called the Watonga Republican. His grandfather was appointed Territorial Governor by Teddy Roosevelt in 1901, before Oklahoma became a state, while his grandmother continued to run the paper for more than 30 years. ${ }^{1}$

Dr Ferguson's father, Walter Scott Ferguson, first began writing a political column "Over the Tea Cup" at the age of 17. Lore has it that the column contained so much inside information that Walter had to be snooping about the governor's office from time to time. Walter was barred from political discussions by the Governor's advisors, but by then his reputation as a controversial writer was entrenched. Walter met Lucia Loomis at the University of Oklahoma, and after they wed they moved to Northwest Oklahoma and bought the local newspaper, the Cherokee Republican. Walter went into banking after a few years and was a very active legislator after Oklahoma became a state. One of his famous quotations was, "A legislator must always respect the views of his opponents, even if he does not agree with them," recalled Dr Ferguson, a quotation he felt was particularly relevant given the "harangue and fighting that the national legislature is carrying out today." Dr Ferguson's mother stayed in the newspaper business and became one of America's best-known syndicated columnists for more than 4 decades. Her daily column, “A Woman's Viewpoint," was picked up by the Scripps-Howard syndicate and published in 69 newspapers across the country.

\footnotetext{
From the Division of Cardiothoracic Surgery, Washington University School of Medicine, St Louis, Mo.

Disclosures: Author has nothing to disclose with regard to commercial support. Received for publication June 4, 2013; accepted for publication June 11, 2013.

Address for reprints: Marc R. Moon, MD, Joseph C. Bancroft Professor of Surgery, Division of Cardiothoracic Surgery, Washington University School of Medicine, 660 S Euclid Ave, Box 8234, St Louis, MO 63110 (E-mail: moonm@wustl.edu). J Thorac Cardiovasc Surg 2013;146:251-4 $0022-5223 / \$ 36.00$

Copyright (c) 2013 by The American Association for Thoracic Surgery http://dx.doi.org/10.1016/j.jtcvs.2013.06.001
}

Dr Ferguson's interest in medicine emanated from his maternal grandfather, Dr Enos Loomis from Boggy Depot, Oklahoma. Dr Loomis was a country doctor "in every sense of the word." He used to make rounds on horseback at the turn of the century and was affectionately called "Mammy's God" as he visited the small towns and villages that dotted the Choctaw Indian Territory. "My grandfather was not an outstanding doctor," Dr Ferguson noted, "but he was a human being who really cared about other human beings, which is . . . what being a physician is all about." The empathy his grandfather showed to all those around him, regardless of color or creed, was something Dr Ferguson admired, even at a young age. He later strived to emulate this compassion in his own surgical practice.

Dr Ferguson attended Duke University and graduated from medical school in 1947. After 3 years of general surgical training at Duke and a 2-year tour in the Army, he came to Washington University in Saint Louis to train in thoracic surgery with Evarts Graham (10th AATS president) and Tom Burford (51st AATS president). Dr Ferguson joined the Washington University faculty and the staff of Barnes Hospital in 1956. After a short stint in southern Florida in the early 1960s, he returned to Washington University and remained on the academic faculty until his passing at the age of 90. Education and training was of paramount importance to Dr Ferguson, a passion he adopted from his mentors Drs Graham and Burford (Figure 1). He was directly involved in training residents and fellows for 37 years before reaching emeritus status in 1994. Then, in the second half of his nearly 60-year academic career, his focus shifted toward editorial responsibilities and administration at the national level.

Dr Ferguson took over the reins as editor of the Annals of Thoracic Surgery from Herbert Sloan (60th AATS president) in 1984 and maintained this position for nearly 17 years, the longest tenure of any Annals editor. "Printer's ink is in our blood!" he quipped, noting that his wife of 65 years, Elizabeth "Libby" Shanley, was the publisher of the wildly popular St Louis Magazine for more than 16 years (Figure 2). Libby bought the failing rag from a family friend for $\$ 1$ and turned it into the premier lifestyle magazine for the Gateway City. Dr Ferguson had met Libby at Duke, and they were married in 1948. They had three children, Linda (Benoist), Scott, and T. Bruce, Jr,

\footnotetext{
* All Dr Ferguson's quotations are drawn either from his AATS Past President Interview (May 2010, pending publication at the AATS Centennial) or from a personal conversation (May 2013) unless otherwise noted.
} 




FIGURE 1. Dr Ferguson on teaching rounds at Barnes Hospital. (Photo courtesy of Historical Archives, Bernard Becker Medical Library, Washington University School of Medicine.)

a cardiothoracic surgeon who has championed the use of the STS National Database as an educational and quality control tool (Figure 3). Dr Ferguson enjoyed golf and was an avid tennis player, even in his later years, often meeting on the court with his successor from the Annals, Hank Edmunds, for a friendly match.

Dr Ferguson was an active member of the American Board of Thoracic Surgery for more than a decade, and chairman from 1977 to 1979 . He felt strongly that the Board should be held accountable for shaping the future of thoracic surgery by initiating and directing necessary reforms. ${ }^{3}$ During his tenure as president of the American Board of Medical Specialties ending in the early 1980s, his primary objective was an educational campaign to inform the public of the importance of board certification. He noted that one of "medicine's great paradoxes" was how hard we strive

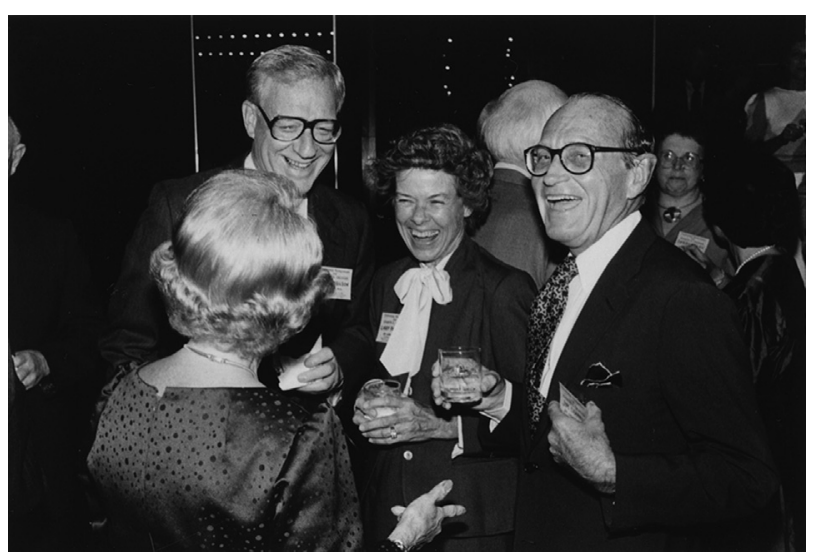

FIGURE 2. Dr and Mrs Ferguson with friends at the Centennial Symposium for Evarts Graham in 1984. The transactions of this memorial symposium were published in the November 1984 issue of the Journal for Thoracic and Cardiovascular Surgery. (Photo courtesy of Historical Archives, Bernard Becker Medical Library, Washington University School of Medicine.)

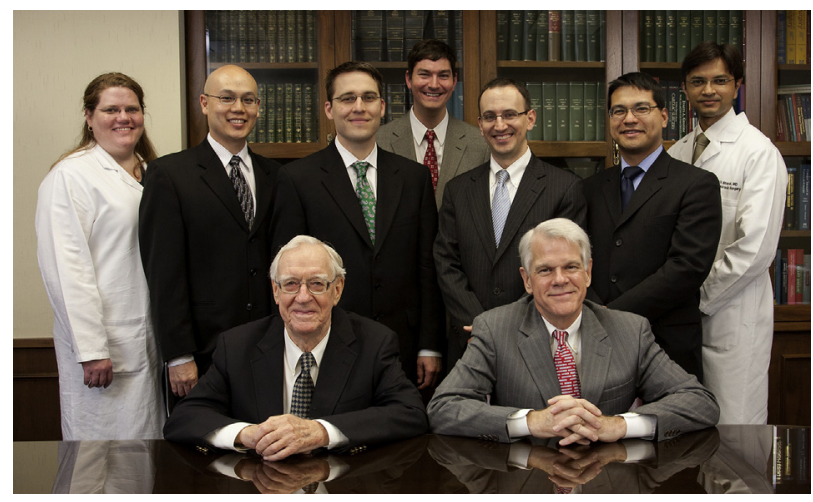

FIGURE 3. Dr Ferguson (front left) and son Bruce (T. Bruce Ferguson, Jr, front right) with the cardiothoracic surgical residents at Washington University in St Louis in 2012. Bruce was the 20th Distinguished Thomas B. Ferguson Visiting Professor in May 2012.

to achieve certification but how little we inform the public of the safety implied in the document ${ }^{2}$ :

If even half the care and attention the average American family exercises in selecting a home or an automobile were applied to the selection of a physician, I am convinced medical litigation would decrease markedly.

But he placed the onus on us as surgeons to spread the word $^{2}$ :

The physician is responsible for making his own credentials, particularly board certification, known to the public.

Dr Ferguson's call to educate the public led to substantial promulgation of our Board's mission "to protect the public by promoting effective, safe and ethical thoracic surgical practice by maintaining high standards for education, training and knowledge."

Dr Ferguson presided over the 62nd Annual Meeting of the AATS in Phoenix in 1982. His presidential address was titled, "The Crisis of Excellence." ${ }^{2}$ He noted that there was an inverse relationship between medical miracles and medical esteem. The goal of the physician is to eradicate illness, whereas the goal of the patient is to return to normal health. This leads to a confusion of objectives. His first example was that after lobectomy, lung cancer is cured and the physician is pleased, but the patient cannot understand why his chest wall is sore. Despite the cure, the patient feels he has not returned to "normal" health. To bridge the gap between the goals of the physician and the goals of the patient, Dr Ferguson focused on three contemporary issues including: (1) manpower manipulation, (2) medical litigation, and (3) cost containment, all issues that remain relevant in 2013.

Regarding physician manpower, Dr Ferguson felt that we should avoid external manipulation. He believed that there was danger in external manipulation of complex systems 
and that intervening was a way to cause trouble. He emphasized, however, that data collection was essential and recommended the national organizations conduct manpower surveys every 5 years. Dr Richard Cleveland presented the 1980 manpower study ${ }^{4}$ at that meeting, and in accordance with Dr Ferguson's mandate these surveys continue today, most recently summarized by Shemin and Ikonomidis in 2012. ${ }^{5}$ Dr Ferguson emphasized that the data should not automatically trigger adjustment; rather, we should defer to the dynamic forces of a free society shaped by the "most sophisticated computer extant, the human brain."

Regarding malpractice, Dr Ferguson preferred the term medical litigation, noting that malpractice has a guiltyuntil-proven-innocent connotation. He was very concerned that the medical community was assuming a posture of what is safe for the doctor, rather than what is best for the patient. Dr Ferguson addressed the concept of "designated compensable events" as a potential mechanism to decrease the number of malpractice suits and the associated stigma. ${ }^{6}$ $\mathrm{He}$ also suggested that a system be put in place to fill the gap between physician and patient that was created by today's science, such as a paramedic, nurse, or social worker, essentially the American equivalent of the "Chinese barefoot doctor."

Regarding cost containment, Dr Ferguson reminded us that medical care as a birthright is not a guaranteed certificate of health. "Increased technology equals increased cost," he said. "There is no free lunch",

As long as the national philosophy promotes restoration of health as a birthright and as long as the sick individual and his loved ones demand, by resorting to court action if necessary, nothing less than firstclass care, medical costs will continue to rise.

He went on to note that life expectancy had increased from 68 years in 1950 to 74 years in 1980, but that health care spending had more than doubled from $4.5 \%$ to $9.4 \%$ gross national product (GNP). To this he questioned, "At what percentage of the GNP do we wish to curtail expenditures in saving human life?" 2 With life expectancy projected near 80 years by 2020 and health care now greater than $16 \%$ GNP, Dr Ferguson's question remains germane today. During our recent conversation he reiterated, "There is no free lunch."

Dr Ferguson was an individual with a unique, profound insight into the human mind, the American psyche, and the public perception of our profession. He was elected 12th Society of Thoracic Surgeons (STS) president in 1976, one of only a handful to become president of both major US thoracic surgical groups (Dr Burford, also from Washington University, was among the first to accomplish this honor). Without a doubt, David Sugarbaker (AATS President) and Doug Wood (STS President) could essentially recite Dr Ferguson's presidential addresses this

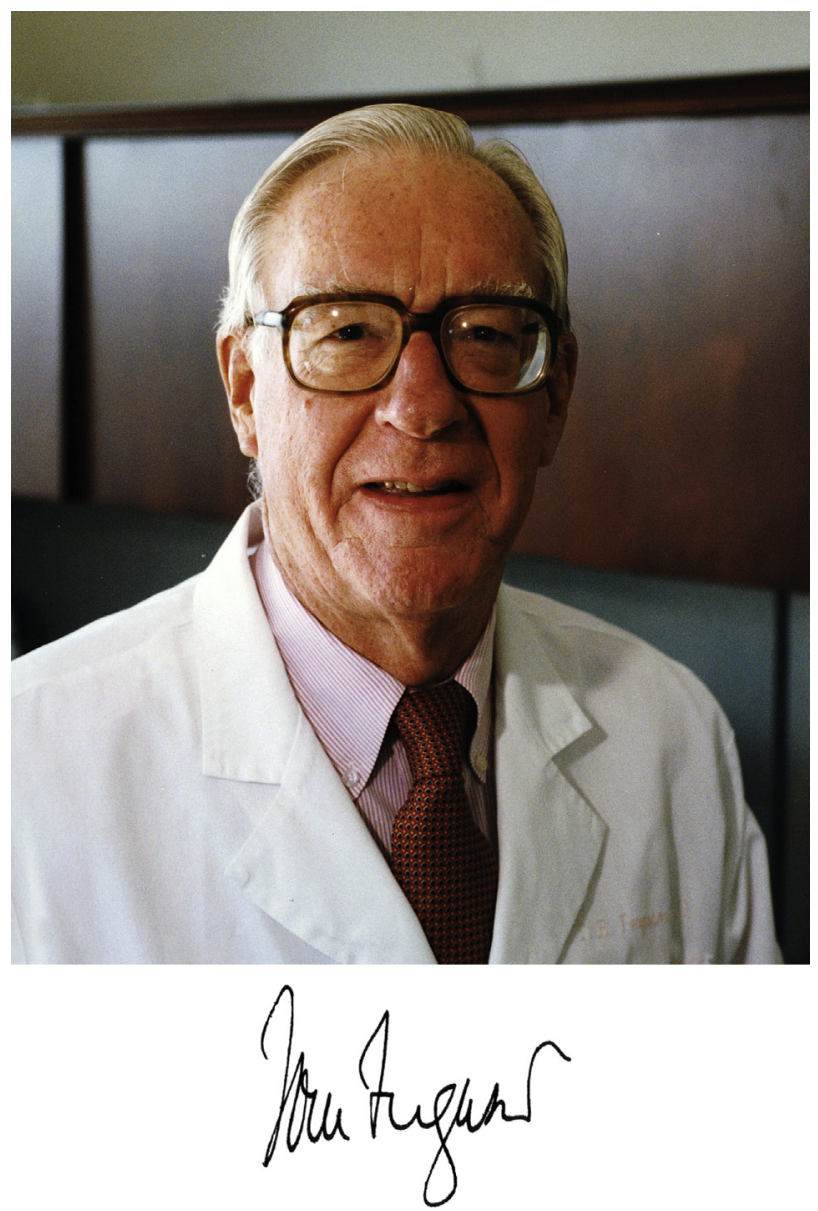

FIGURE 4. Thomas B. Ferguson, MD.

coming year at their respective annual meetings with as much or even more relevance today as when first presented more than thirty years ago.

In the late 1990s, Dr Ferguson continued his quest to move the field of cardiothoracic surgery forward as the founding editor of CTSnet, the online portal for cardiothoracic surgery. Dr Ferguson credits Bob Replogle, cardiac surgeon from Chicago and wine connoisseur, as the padrone of CTSnet. At the European Association for CardioThoracic Surgery Annual Meeting in Prague in 1996, Ferguson, Replogle and other visionaries ironed out the specifics of the website which has become an essential resource as Ferguson noted, "particularly in the third world countries where medical information is hard to come by."

Despite his national recognition for administration and critical editorial contributions, Dr Ferguson fondly remembered that he was "never happier than when I was in the OR." Second only to his passion for clinical work, his favorite assignment was the evaluation and nurturing of medical students. After his retirement from clinical practice, Dr Ferguson served on the medical school admissions committee for 26 years until his passing. Interviewing eager 
applicants was the "one job that I've enjoyed almost as much as surgery." Dr Ferguson was invigorated by the passion, vitality, and dedication of the young applicants:

If there was ever a time that I got downtrodden or worried about what's going to happen to medicine in the future, all I had to do was pull out one of the applicant's files. They are the brightest, most perceptive individuals, so aware of their place in the world.

Among the countless awards Dr Ferguson received during his prestigious career, his most coveted honor was the "Award for Inspirational Teaching" he received from the medical students in 1980.

Reinforcing his pragmatic comprehension of the limits of medical science, Dr Ferguson encapsulated his ultimate lesson to a captive audience of thoracic surgeons more than 35 years ago ${ }^{3}$ in a quotation from Lois Wheeler Snow, " ${ }^{7}$ There is yet a limit to technology; there is none to humanity, beyond our own making."

Dr Ferguson was a fascinating individual; a dedicated family man; an outstanding thoracic surgeon; a pillar of our specialty; and a close friend, advisor, and confidant to so many, over so many generations. Dr Ferguson passed away peacefully May 26, 2013, with his family at his side. I am sure we will all miss Dr Ferguson in the future; in fact, I already do (Figure 4).

\section{References}

1. Oklahoma Historical Society Encyclopedia of Oklahoma history \& culture. Stillwater, OK: OSU Library Electronic Publishing Center; 2007. Available at: http://digital.library.okstate.edu/encyclopedia/toc.html. Accessed June 2, 2013.

2. Ferguson TB. The crisis of excellence. J Thorac Cardiovasc Surg. 1982;84: 161-71.

3. Ferguson TB. Guilds, boards, and hobgoblins. Ann Thorac Surg. 1977;24:6-18.

4. Cleveland RJ, Orthner HF, Bahnson HT, Ferguson TB, Spencer FC, Bonchek LI, et al. The third manpower study of thoracic surgery: 1980 report of the Ad Hoc Committee on Manpower of The American Association for Thoracic Surgery and The Society of Thoracic Surgeons. J Thorac Cardiovasc Surg. 1982;84: 921-32.

5. Shemin RJ, Ikonomidis JS. Thoracic surgery workforce: report of STS/AATS Thoracic Surgery Practice and Access Task Force-snapshot 2010. J Thorac Cardiovasc Surg. 2012;143:39-46, e1-6.

6. Tancredi LR. Designated compensable events: a no-fault approach to medical malpractice. Law Med Health Care. 1982;10:200-3. 215.

7. Snow LW. A death with dignity: when the Chinese came. New York: Random House; 1975. 